\title{
PARA ALÉM DE UMA EDUCAÇÃO MULTICULTURAL: TEORIA RACIAL CRÍTICA, PEDAGOGIA CULTURALMENTE RELEVANTE E FORMAÇÃO DOCENTE (ENTREVISTA COM A PROFESSORA GLORIA LADSON-BILLINGS)
}

\author{
Luís ARMANDO GANDIN* \\ Júlio Emílio Diniz-PereirA* \\ Álvaro Moreira HyPOlito ${ }^{* * *}$
}

RESUMO: O presente texto traz a entrevista da Professora Gloria Ladson-Billings, da Universidade de Wisconsin, nos Estados Unidos. Nessa entrevista, a professora Ladson-Billings analisa conceitos como o de 'teoria racial crítica' e 'pedagogia culturalmente relevante', mostra a importância desses conceitos para a superação de modelos conservadores de Educação Multicultural, bem como discute os desafios que ainda precisam ser enfrentados no campo do currículo e da formação docente, principalmente em relação às questôes raciais. Finalmente, ela fala a respeito do que conhece sobre a realidade educacional brasileira e de como o Brasil poderia participar de um movimento de construção de uma consciência racial crítica mundial.

Palavras-chave: Teoria racial crítica. Pedagogia culturalmente relevante.

Educação multicultural. Formação docente.

\section{Beyond multicultural education: CRitical RaCe theory, CULTURALLY RELEVANT PEDAGOGY AND TEACHER TRAINING (InTerview with Professor Gloria Ladson-Billings)}

ABSTRACT: In this interview, Professor Gloria Ladson-Billings analyzes the concepts of 'critical race theory' and 'culturally relevant pedagogy', emphasizes the importance of these concepts in the process of overcoming

\footnotetext{
* Professor da Universidade Federal do Rio Grande do Sul (UFRGS). E-mail: Luis.Gandin@ufrgs.br

** Professor da Universidade Federal de Minas Gerais (UFMG). E-mail: jdpereira@wisc.edu

*** Professor da Universidade Federal de Pelotas (UFPel). E-mail: hypolito@ufpel.tche.br
} 
conservative models of multicultural education, and discusses the challenges for those working in the field of curriculum and teacher education, especially when they deal with the issue of race. Finally, she comments on her knowledge of the Brazilian educational reality and argues that Brazil should participate in a movement for the creation of a global critical race consciousness.

Key words: Critical Race Theory. Culturally Relevant Pedagogy. Multicultural Education. Teacher Training.

\section{Apresentação}

esta entrevista, a professora Gloria Ladson-Billings aborda temas importantes para a superação de modelos conservadores de Educação Multicultural. Conceitos tais como o de 'teoria racial crítica' e 'pedagogia culturalmente relevante' são centrais em sua argumentação sobre a necessidade de se teorizar a questão racial em educação. Ladson-Billings também discute as relações raciais no Brasil e defende a idéia de que o Brasil participe de um movimento de construção de uma consciência racial crítica mundial.

Gloria Ladson-Billings é professora do Departamento de Currículo e Ensino (Curriculum and Instruction) da Universidade de Wisconsin, nos Estados Unidos, e uma intelectual internacionalmente respeitada por seus trabalhos no campo do Currículo e Educação Multicultural. A professora Ladson-Billings concedeu esta entrevista em setembro de 2001, em seu gabinete.

Entrevistadores: - Você, William Tate e outros são responsáveis por introduzir a teoria racial crítica no campo da educação. Por favor, explique quais são as premissas da teoria racial crítica e porque é importante incorporá-la às teorias e práticas educacionais?

Gloria Ladson-Billings: - Uma das premissas é que a noção de raça não tem sido suficientemente teorizada. Há significativa teorização a respeito de classe e gênero, mas há muito pouco sobre a questão da raça. Parte do que existe apenas enfatiza a inferioridade genética e mesmo o marxismo e o neo-marxismo não falam suficientemente de raça. No entanto, sabemos que raça é uma categoria importante. Essa é, portanto, a base do esforço de constituir a teoria racial crítica. Em uma sociedade capitalista, essa teoria é profundamente necessária porque a sociedade fundamenta-se na propriedade e no direito de propriedade. Uma das coisas absurdas que aconteceu na história dos Estados Unidos é que seres humanos foram transformados em propriedade. Depois disso, o que 
ocorreu foi a transmutação de propriedade para cidadão. Essa não foi uma transição suave e contínua, ainda há muita tensão envolvida: Quem é o outro? De que maneira esse outro passou a ter algum direito como cidadão? Isso sintetiza as intenções e os questionamentos dessa teoria.

A teoria racial crítica oferece um questionamento do direito tradicional. O direito estadunidense é baseado em precedentes de casos judiciais. Além desse questionamento, buscam-se outras versōes, histórias alternativas. Quando surge algo numa corte, ou em um dossiê judiciário neste país, o que temos é um simples "Esta é a história". O que a teoria racial crítica diz: "Há uma outra história a ser contada". Ela baseia-se fortemente na recuperação da história e da memória em oposição ao tradicional, empírico e estéril "Estes são os fatos"; "Isto foi o que aconteceu”. A teoria racial crítica também se baseia em uma combinação de disciplinas, não se limitando ao Direito. Na Educação, por exemplo, outras áreas do conhecimento, tais como Sociologia, Antropologia e uma variedade de outras disciplinas são usadas para analisar os fenômenos educacionais desde uma perspectiva crítica. Essas são as premissas básicas da teoria racial crítica. O que tentamos fazer no campo da educação foi partir da perspectiva de que raça é importante, mesmo que pouco teorizada, direitos de propriedade são, por assim dizer, o que sustentam a sociedade e, portanto, a intersecção entre raça e propriedade oferece um interessante objeto de estudo. Passamos a nos interessar por temas ligados à educação escolar. Se olharmos, por exemplo, para o currículo, ele é 'racializado' mas também é uma propriedade intelectual. Nas escolas pobres que atendem crianças não brancas a qualidade da propriedade intelectual é inferior a das crianças brancas de escolas de classe média. $\mathrm{O}$ financiamento é diferente. A própria infraestrutura oferecida às crianças das comunidades empobrecidas está em condições precárias. A metodologia é diferente. Nas escolas que atendem crianças pobres, negras e de outras minorias raciais, encontra-se um tipo de ensino 'de cima para baixo', muito autoritário, que apenas reforça o baixo status dessas crianças. Esse tipo de educação não constitui um empreendimento intelectual; procura-se manter o corpo dessas crianças sob controle, mantê-las quietas na sua carteira sem fazer perguntas, não criticando o sistema e apenas fazendo o que se ordena.

É importante ressaltar que o nosso trabalho neste momento tem sido a construção de um instrumental teórico e não uma fixação nas questóes pragmáticas. Mesmo no campo do Direito, onde a teoria racial crítica surgiu, não há evidência até o momento da sua aplicação direta em tribunais. Permitam-me citar um exemplo de como a aplicação prática 
dessa teoria ainda é problemática. Lani Guinier, uma pessoa interessada em questôes de raça, mas não necessariamente uma estudiosa da teoria racial crítica, quando foi nomeada por Clinton para a Secretaria de Direitos Civis, foi crucificada por suas declarações de que enquanto tivermos minorias na sociedade, a fórmula 'uma pessoa, um voto' nunca assegurará que a voz dessas minorias seja ouvida. Essa posição foi considerada uma heresia. Ela foi acusada de ser 'antipatriótica'. Mas, na realidade, ela se referia aos brancos da África do Sul no período pós-apartheid. A fórmula 'uma pessoa, um voto' não permitiria que a voz dos brancos fosse ouvida na 'nova' África do Sul. A fórmula 'uma pessoa, um voto' é um ponto nevrálgico nesta sociedade e, por isso, o seu questionamento fez com que as pessoas lhe criticassem. Este exemplo mostra que a teoria racial crítica ainda não se firmou na prática do Direito. Não há ainda advogados que defendam seu caso baseado na teoria racial crítica. $\mathrm{Na}$ educação, essa teoria tem servido como uma ferramenta analítica para o exame das desigualdades.

$E:$ - Você tem conhecimento de algum estudo empírico que use a teoria racial crítica e que procure implementá-la como princípio teórico?

GLB: - O Direito baseia-se em precedentes e, por isso, as pessoas que se interessam por teoria racial crítica no Direito examinam atentamente esses precedentes e os rearticulam. Um exemplo de estudo relacionado com essa teoria é a pesquisa conduzida por uma professora que trabalhou na Faculdade de Direito da Universidade de WisconsinMadison, mas que agora está na Vanderbilt University, chamada Beverley Moran. Ela é uma advogada especializada em causas fiscais e fez uma análise empírica que avaliava os impostos pagos ao longo dos anos. Ela conclui que os negros pagam mais impostos, pois não têm os recursos para contratar um contador ou alguém que cuide da sua declaração de renda e planeje suas finanças e, portanto, acabam não obtendo todas as deduções possíveis garantidas por lei. Isso faz com que, ao longo do tempo, os negros paguem mais impostos do que os pagos por uma pessoa branca de classe média. Este é um exemplo de estudo empírico que usa elementos da teoria racial crítica para afirmar que há uma desigualdade racial no pagamento dos impostos.

$E:-E$ na educação? Há exemplos de estudos empíricos baseados nessa teorização?

GLB: - Há uma nova corrente de estudiosos surgindo, chamada LatCrits (estudiosos dos temas latinos que usam a teorização racial crítica), pessoas como Daniel Solorzano, Sofia Villenas e Kris Gutiérrez estão examinando há algum tempo questôes ligadas a essa teorização, mas não 
acho que alguém já tenha feito estudos empíricos totalmente baseados na teoria racial crítica.

Além disso, há uma intersecção entre as áreas do Direito e da Educação. Derek Bell, por exemplo, dedicou grande parte de seus estudos na área do Direito ao exame do fim da segregação escolar. Um de seus argumentos básicos, fundamentados em seus estudos e na teoria racial crítica, é que nunca houve nenhuma legislação de direito civil proposta ou votada nos EUA que não tenha beneficiado os brancos. Ele, na realidade, examinou alguns exemplos do passado, através de narrativas históricas. Ao examinar, por exemplo, o movimento de eliminação da segregação escolar - que deveria estar ajudando as crianças negras ou latinas que passam a freqüentar as 'escolas melhores' -, Bell demonstra que o que essa legislação costuma fazer é criar mais fundos nessas escolas brancas para contratar mais docentes, contratar profissionais para trabalhar com o professorado, contratar mais motoristas de ônibus escolares para transportar as crianças e para comprar mais material de consumo. Assim, há mais recursos destinados às chamadas 'escolas sem segregação', mas estes não são necessariamente destinados às crianças e à sua educação.

$E$ : - Como você responderia às criticas que afirmam que ao se privilegiar demasiadamente a raça em detrimento da classe, em particular, mais também do gênero e da sexualidade, a teoria racial crítica não nos ajuda a entender e a agir melhor numa sociedade em que as opressóes raciais de gênero, de sexualidade e de classes são tão estreitamente entremeadas?

GLB: - Esta é uma ótima pergunta. Bem, permitam-me voltar, primeiro, ao meu argumento de que a raça tem carecido de teorização. Academicamente, a noção de raça vive um importante momento de recuperação, no qual se tem buscado uma maior precisão a respeito do que queremos dizer quando usamos esta noção. Mas se lermos atentamente o trabalho dos estudiosos ${ }^{1}$ da teoria racial crítica, vamos perceber que este também está interessado nas questões de classe e de gênero. Por exemplo, tenho uma ex-aluna que recorre a uma análise de classes no seu trabalho, mas o centro do seu interesse é o desenvolvimento de estratégias anti-racistas. Não creio que um exclua o outro. $\mathrm{O}$ fato de dizer que faço uma análise crítica de raça não significa que eu ignore as questões de gênero. Também não significa que não estou considerando as questões de classe. Todas essas categorias estão entremeadas. Mas necessitamos de uma ferramenta em nossa análise, de um ponto de entrada. O que costuma acontecer quando achamos estar usando todas essas ferramentas ao mesmo tempo, é que acabamos por lutar para tentar fazer com que a 
análise faça sentido. A teoria racial crítica usa a raça como este ponto de partida para a análise.

A noção de raça tem que ser, no entanto, complexificada. Classes sociais são reais no sentido de que podemos encaixar as pessoas na hierarquia econômica. Gênero é real no sentido de que podemos pelo menos falar um pouco a respeito de biologia, de sexualidade. Mas a raça é um alvo móvel. O que é branco neste lugar não o é naquele. Isto acontece mesmo nos Estados Unidos. Há um livro maravilhoso chamado How the Irish became white (Como os irlandeses se tornaram brancos). Os irlandeses não foram sempre brancos nos Estados Unidos: ser branco é um privilégio social concedido às pessoas. Se formos checar suas verdadeiras bases, ser branco não tem uma relação direta com a biologia. $\mathrm{O}$ exemplo mais notável disto é o caso O. J. Simpson. Este é um dos exemplos mais explícitos do quão mutável é o significado da raça. A meu ver, o verdadeiro crime que Simpson cometeu não foi simplesmente ter assassinado duas pessoas, mas ter recebido por tanto tempo uma espécie de 'branquidade' honorária e a ter traído. Ele tinha ascendido econômica, social e politicamente no espaço dos brancos e eles o tinham aceitado. Quando veio o julgamento, os brancos se sentiram traídos: "Achávamos que ele fosse um dos nossos". Há algo que mostra com muita clareza este sentimento: no segundo processo sofrido por Simpson - o processo civil no qual se determinaria o quanto ele teria que pagar em danos -, ele foi condenado a pagar uma quantia astronômica de dinheiro. Entretanto, foram até a sua casa para confiscar duas coisas: o troféu Heisman (aquele troféu dado a jogadores de futebol americano que mesmo se for derretido não tem qualquer valor monetário) e os seus tacos de golfe. Isso não tem nada a ver com a condenação multimilionária. $O$ verdadeiro significado deste gesto é a expropriação desses símbolos da branquidade que lhe haviam sido concedidos. "Você não vai mais ter tacos de golfe".

Assim, não peço desculpas por usar a noção de raça como uma maneira de olhar para as desigualdades sociais, porque sei muito bem que há várias pessoas que continuam a estudar gênero, a estudar sexualidade. Se, através de uma análise racial, eu encontro uma boa resposta acerca das desigualdades sociais, não vou guardá-la só para mim. As pessoas que trabalham com gênero e classe são muito mais do que bem-vindas se quiserem usá-la.

Um problema que enfrentei ao usar a noção de classes sociais na minha tese foi que, ao olhar para as classes entre as comunidades de jovens cidadãos afro-americanos e brancos na Califórnia, esbarrei no fato de que classe tem significados diferentes na comunidade negra e na 
branca. Entretanto, a maioria dos sociólogos, os antigos da Escola de Chicago, tal como Talcott Parsons, havia determinado um sentido certo e único para o conceito de classe. Contudo, o que é classe operária para os brancos nesta sociedade costuma ser classe média para os negros. Se pensarmos em empregos como motorista de ônibus, funcionário dos correios, são empregos da classe operária, na sociedade mais ampla. Contudo, um funcionário dos correios numa comunidade negra é considerado da classe média, pois possui estabilidade de emprego, benefícios sociais e pode comprar a casa própria. E isto explica porque os políticos, nesta sociedade, falam acerca da classe média. Em nenhum outro lugar do mundo, alguém tentaria ser eleito dizendo que vai tentar ajudar a classe média. Seria ridículo tentar ser eleito no México dizendo: "Vamos fazer todo o possível para ajudar a classe média". Mas nos Estados Unidos, todo candidato diz que temos que ajudar a classe média. Por quê? Porque nos Estados Unidos quase todos acabam encontrando um jeito de se considerarem classe média. E os que não o fazem estão privados de seus direitos cívicos a tal ponto que não vão sequer votar. Mesmo aqueles que mal conseguem pagar suas contas vão lhe dizer que pertencem à classe média. A discussão que não temos em nossa sociedade é a de saber o que aconteceu com a classe operária. A literatura a respeito dos afro-americanos costuma enfocar os pobres e as chamadas subclasses. Existe alguma literatura a respeito da classe média negra, porque ela surgiu, por assim dizer, da revolução cultural das lutas a respeito dos direitos cíveis. Mas a classe operária negra, que é o maior grupo, é ignorada. Fizeram com que pensasse a si mesma como classe média.

E: - No seu livro The dreamkeepers: Successful teachers of AfricanAmerican children (Os guardioes dos sonhos: Professores bem-sucedidos de crianças afro-americanas), publicado em 1994, você usa o conceito de pedagogia culturalmente relevante. Poderia nos explicar em que consiste este conceito? Há alguma influência de Freire nesta sua formulação?

$G L B$ : - Penso basicamente na pedagogia culturalmente relevante como um triângulo ou um tripé. Uso esta imagem para evitar a idéia de uma hierarquia de componentes, o que não é o caso. Um dos vértices é o que chamei de desempenho escolar. Este vértice insiste que as crianças precisam aprender na escola. Não faz sentido mandarmos as crianças para a escola todos os dias, todos os anos se elas não aprenderem nada. Não podemos aceitar que elas saiam da escola sem saber ler, sem saber nada de matemática, de história. Entretanto, e isto é essencial, a abordagem de desempenho escolar na pedagogia culturalmente relevante não se limita a incutir informações nas crianças. Ela ajuda as crianças a desenvolverem 
uma análise crítica a respeito do que estão aprendendo, a levantarem questões do tipo: "Mas porque é desse jeito?". Ensina as crianças a tomarem as rédeas de seu próprio aprendizado, a irem atrás do tipo de coisas que acham importantes. A verdade é que não podemos justificar o pagamento de quem não faz aquilo que é pago para fazer: ensinar. E, na realidade, isso é o que acontece em uma parte substancial das escolas de periferia. $\mathrm{Na}$ realidade, elas não ensinam muito. São locais onde as crianças passam os seus dias, sem aprender quase nada. E estas são as boas escolas, porque as ruins são prisões que apenas prendem as crianças neste espaço. Por estas razōes eu insisto que o desempenho escolar tem que ser um dos objetivos desta pedagogia.

O segundo vértice é o que chamo de competência cultural. Com este conceito quero me referir à capacidade das crianças entenderem quem elas são, de onde vêm e porque estas coisas são importantes para ajudá-las na aprendizagem. E isto nada tem a ver com um professor que diz: "Tudo bem, vamos afixar pôsteres de Michael Jordan ou vamos escutar músicas do Ricky Martin". Esta é uma abordagem muito superficial - um dos meus alunos chamava isso de 'rapinagem cultural': "Vou pegar só um pouquinho de tuas coisas e colocar aqui". Isto, na verdade, não serve para nada. $\mathrm{Ou}$, pior, no caso das crianças negras, traz um perigo muito grande que é tornar a cultura dos rapazes negros em uma mercadoria incrível. Não há lugar neste mundo, praticamente, em que não se escute música rap. Não há lugar, praticamente, em que não vemos roupas e posturas da cultura dos rapazes negros. Está nos filmes, nos vídeos. Entretanto, isto não é exatamente cultura negra, é cultura jovem; todo grupo de jovens cria sua própria cultura. $\mathrm{O}$ que as crianças afro-americanas não sabem - $\mathrm{e}$ o que a pedagogia culturalmente relevante busca ajudá-las a entender - é que parte central da sua cultura é a luta pela educação. Os afro-americanos lutaram e alguns morreram para obter educação. É uma cultura que não se opôs a educação, mas que insistiu na necessidade de conquistá-la. É uma cultura de pessoas que, mesmo com leis que as proibiam de aprender a ler, insistiam nesta busca. Esse é um processo, portanto, quase arqueológico de escavar, de desenterrar estes elementos da cultura afro-americana. Esta é uma forma de ajudar as crianças e adolescentes a entenderem que elas podem ser inteligentes e 'legais' ao mesmo tempo. $\mathrm{Na}$ verdade, a maioria delas não pensa assim. Eles acham que têm que escolher: ou sou 'C.d.F.' ("Não tenho contatos com minha comunidade, só vou para escola e sou bom aluno") ou sou 'malandro' ("Participo das atividades da minha comunidade e a escola não serve para nada"). A noção de competência cultural ajuda os alunos e os professores a fundirem esses dois tipos. 
Isto nos leva ao terceiro vértice, que é a consciência sociopolítica, e é aqui que a influência de Freire aparece. A noção de consciência sociopolítica nos ajuda a entender que se temos apenas crianças e adolescentes inteligentes e culturalmente seguras, então temos apenas um grupo de indivíduos que pensam 'sou inteligente, sou legal' e não sei porque vocês não são. Eles acham que chegaram aí sozinhos. A consciência sociopolítica serve para fazer com que eles entendam que os estudos que fazem na escola e o que aprendem aí têm um objetivo social maior. Este aprendizado deveria estender-se além da sala de aula, deveria preparálos para perguntar: "Por que existem esses padrôes de desempenho escolar?", "Por que crianças que falam uma linguagem diferente parecem nunca ter acesso às classes avançadas de matemática?", "Por que tantas crianças e adolescentes de cor abandonam a escola?". Este é o tipo de perguntas que a consciência sociopolítica ajuda a fazer. Ela ajuda as crianças e adolescentes a olharem não apenas para o seu próprio desempenho escolar. Numa sociedade que glorifica o desempenho individual, isto é absolutamente necessário. Eu vi professores trabalharem problemas sociais com crianças bastante jovens com bastante sucesso. No meu novo livro, eu trago o exemplo de uma professora que fez um trabalho com os seus alunos e os fez perceber que o restaurante Pizza Hut é parte do grupo empresarial da Pepsi-Cola e que a Pepsi-Cola apoiou a opressão no Tibete e em Burma. As crianças não sabiam onde era Burma. Também não entendiam exatamente o que era opressão. Mas o que ela fez eles entenderem é que quando um grupo faz algo ruim para muitas pessoas e ao mesmo tempo lhe oferece algo que diz ser muito bom, será que o que estão lhe oferecendo é tão bom assim? As crianças, neste caso, poderão começar a se dar conta: "Não, na verdade isso não é tão bom". Eles gostam da pizza do Pizza Hut. É o tipo de comida que as crianças adoram. Como a gente lida com isso? Estas crianças acabaram colocando cartazes por toda a escola pedindo para que os outros alunos boicotassem a pizza do Pizza Hut e tentaram fazer com que a escola contratasse outra empresa de pizza. Em outras palavras, as crianças passaram a pensar: "Isto é um assunto mais importante que o meu gosto. Adoraria comer um pedaço de pizza do Pizza Hut, mas tenho que ver o problema que é maior do que a minha vontade individual". Este é o tipo de trabalho que professoras como esta estão conseguindo fazer. Penso que aqui há uma relação com o trabalho de Paulo Freire. Creio que este tipo de engajamento com temas que vão além do individual é libertador: "Não posso pensar só em mim". O que realmente me deixa frustrada quando falo com crianças que estão com dificuldades na escola é elas pensarem que a 
culpa é delas e somente delas. Elas vivem dizendo-nos porque elas são as culpadas: "Não fiz isso. Deveria ter feito aquilo". É muito difícil para elas enxergarem o quadro social mais amplo. Professores que trabalham com a pedagogia culturalmente relevante têm começado a insistir nestes aspectos sociais mais amplos com as crianças muito jovens. Eles estão começando a colocar esse tipo de perguntas e as crianças e adolescentes nas escolas estão começando a entender que elas precisam buscar espaços para reagir, que elas podem fazer alguma coisa. Dia desses, vi um exemplo numa escola que parece meio bobo, mas é bastante interessante. Uma menina tinha visto que o menu de almoço para aquele dia previa um sanduíche feito com croissant. Ela foi feliz comprar o sanduíche, que, para sua surpresa, era feito com pão de hambúrguer. E ela ficou tão chateada com isto que organizou um movimento de protesto com todas as outras crianças: "Porque estão mentindo para a gente? Se quiserem servir isto, tudo bem, mas nos digam que vai ser assim". Isto fez com que as outras crianças pensassem em quais eram as outras maneiras em que a escola não estava dizendo a verdade, de que outras maneiras elas eram enganadas. Com isto chegaram a uma espécie de análise crítica das diversas propagandas que vêem na televisão, e assim por diante. Se conseguirmos criar este tipo de cidadãos, então não teremos porque nos preocupar com o tipo de políticos que existirão na sociedade. No momento, contudo, não há muitas pessoas capazes de serem críticas, motivo pelo qual temos todas essas dificuldades. Somos incapazes de ver além da superfície, somos incapazes de ver além do que a propaganda nos mostra.

E: - No seu último livro, Crossing over to Canaan: The journey of new teachers in diverse classrooms (Travessia para Canaã: A jornada dos novos professores para salas de aula com diversidade cultural), publicado nos Estados Unidos, em 2001, você analisa a situação dos professores nos Estados Unidos e, em particular, o programa chamado "Teach for diversity" ("Ensinar para a diversidade"). Você poderia relatar algumas das suas conclusões neste livro, principalmente acerca dos problemas de formação de professores e a implementação de abordagens multiculturais em escolas públicas?

$G L B$ : - Bem, essa questão é difícil, pois eu poderia falar por várias horas sobre a questão da formação de professores. No livro eu ofereço uma metáfora: a formação de professores é como uma estrada com pedágio. Dirigimos na estrada e chegamos num exame de admissão. Continuamos dirigindo e temos que fazer vários créditos na faculdade. Dirigimos um pouco mais e temos que fazer um estágio. Todo mundo está dirigindo na mesma estrada e passando pelos mesmos pedágios. Mas nem todo mundo 
é igual e o desenvolvimento de cada um não é levado em consideração. A formação de professores, particularmente nos Estados Unidos, não está fundamentada em uma base teórica e intelectual. Não nos importamos muito com a vida intelectual de nossos professores. Entretanto, há quem diga: "Eles não sabem muita coisa e, portanto, não ensinam quase nada". O problema é que a formação de professores é regida pela burocracia estatal e por isso pode acontecer de se ter alguém que não entende nada de educação ou, pior, que crê que entende, como o responsável por formular as diretrizes dessa formação. Assim, temos coisas sem pé nem cabeça incluídas na formação de professores. Temos um organismo externo controlando a formação dos professores e este organismo não tem muito interesse em ajudar a criar espaços e oportunidades para que as pessoas se desenvolvam intelectualmente. É por isso que o conceito de Henry Giroux de 'professores como intelectuais transformadores' é totalmente estranho para o professorado estadunidense de hoje. E as pessoas quase nunca percebem isto até estarem envolvidas a bastante tempo com o trabalho docente. E aí dizem: "Eu não estou fazendo muito, não estou ajudando muito". Mas até se conscientizarem disto leva um tempo.

Uma das minhas preocupações é que ficamos educando pessoas com 18, 19 anos para ensinar nos ambientes mais difíceis, a respeito dos quais não têm a menor experiência. Elas chegam cheias de boa vontade e são inteligentes, no sentido convencional. São bem informadas, passam nos exames, mas chegam com uma experiência muito limitada para trabalhar com pessoas que são diferentes delas. Eles chegam com uma experiência de mundo muito limitada. Muitas delas viajaram muito, mas apenas como turistas, não vivenciaram nenhum lugar diferente de verdade. E quando mostramos a elas, por exemplo, como os Estados Unidos, em suas relações com o resto do mundo, ajudaram a criar as desigualdades globais, eles não têm condições de conduzir essas conversas, não têm mesmo. E se não são capazes de conduzir essas conversas, não estão preparadas para ajudar as crianças nas escolas a participarem desse tipo de conversas. Assim, temos um enorme problema de conhecimento e da relação deste conhecimento com o social.

Um outro aspecto é a falta de experiência dos candidatos a professor. Se você tem 19 anos, não pode ser condenado por ter essa idade, mas você pode não estar realmente pronto para ser professor.

Além disso, temos uma tensão no professorado dos Estados Unidos - algo que está relacionado ao meu comentário anterior sobre todos se considerarem classe média. $\mathrm{O}$ professorado é ambivalente: não sabem se são trabalhadores ou profissionais. Quando chega o momento de negociar 
o contrato de trabalho eles se consideram trabalhadores, mas em muitas outras oportunidades desejam ser considerados profissionais: querem ser empreendedores, querem trabalhar sozinhos, não querem trabalhar em projetos coletivos de elaboração do currículo, não querem trabalhar coletivamente para mudar as desigualdades de financiamento e as situações que afastam algumas crianças e adolescentes das melhores oportunidades.

Estes são os problemas gerais na formação docente, mas também existem problemas mais específicos a respeito da noção de educação multicultural. Não acho que a formação de professores nos Estados Unidos, em geral, seja muito boa. As dificuldades aumentam quando introduzimos essa noção de que temos de ser capazes de educar bem todas as crianças, que devemos ser capazes de nos tornarmos mais multiculturais. Eu tenho questionado a utilidade deste termo, multicultural, pois ele, hoje, praticamente perdeu toda a sua força, uma vez que todos se acham multiculturais, até as grandes lojas de departamento. Então o que significa ser multicultural? Eu prefiro insistir em discutir como podemos construir consciências críticas nas escolas. Se conseguirmos construir esta consciência crítica, estaremos lidando com as questôes culturais, de raça, classe, gênero, linguagem e todo o tipo de diferenças. Se o professorado não tem vida intelectual, não é capaz de ser crítico. Devo enfatizar que não entendo intelectual, aqui, como aquele que lê muitos livros. Intelectual para mim é quem é capaz de engajar-se em um diálogo crítico com o mundo. Conheço muitas pessoas que não têm educação formal, mas são muito mais críticas do que as que passaram pela formação de professores. Muitas das pessoas que passaram por essa formação não aprenderam a ler nas entrelinhas e além das páginas de um texto. Elas apenas dizem: "Olha, está no livro, é isto que acontece". E, quando você lhes dá um livro que as desafia, elas simplesmente não aceitam ou dizem: "Tenho este livro que diz $\mathrm{X}$ e aquele que diz $\mathrm{Y}$, e não sei como chegar a um entendimento que seja meu partindo dessas duas noções conflituosas". No nosso programa, seguidamente indicamos textos de Howard Zinn (um historiador estadunidense que questiona a 'história oficial' dos Estados Unidos) para leitura e muitos dos nossos simplesmente os rejeitam. Isto acontece porque estes textos mostram uma história que contradiz aquela que lhes foi ensinada como verdadeira. Existem algumas 'verdades' intocáveis em nossa história. Por exemplo, quando se 'celebrou' os quinhentos anos da chegada de Colombo à América, houve um debate muito grande sobre o que dizer a respeito de Colombo. Os próprios historiadores declaravam: "As pessoas estão chocadas com o que estamos mostrando sobre Colombo. Temos muito mais a dizer sobre Thomas 
Jefferson (o terceiro presidente estadunidense), mas não ousamos dizêlo agora, porque as pessoas ainda estão irritadas sobre o que dissemos a respeito de Colombo". Se alguém se identifica como intelectual, uma das coisas que deve fazer é tentar obter uma idéia cada vez mais apurada da realidade, dos fenômenos sociais. Desse modo, a verdade da terçafeira pode não ser a da quarta-feira, não porque há múltiplas verdades, mas porque se trata de um processo de aproximação dessa verdade. Se você parou no tempo e decidiu: "Esta é a verdade: Jefferson é uma pessoa admirável”, então você não pode levantar questôes a respeito das contradiçōes entre Jefferson, o homem da liberdade, e Jefferson, o dono de escravos. Não pode falar sobre Jefferson, a pessoa que visivelmente detestava os negros e pensava que eles eram inferiores, e Jefferson, o homem que ia para a cama com uma mulher negra e teve vários filhos com ela. Mesmo a 'ciência', tão reverenciada no Ocidente, revela por meio de exames de DNA que Jefferson era pai dessas crianças. As pessoas não querem falar sobre isso, não se pode conversar a respeito. Não há uma disposição para nos aproximarmos da verdade. Já decidimos qual é a verdade. E queremos que nossas escolas sejam organizadas desse modo. Nossos professores apóiam-se nesse mesmo paradigma: "Já conheço a verdade; ensinem-me apenas como transmitir tudo isso aos alunos".

Conseqüentemente, estou realmente preocupada com a vida intelectual dos nossos docentes. Se tivesse que remodelar a formação de professores, eu exigiria que os estudantes se especializassem em uma área do conhecimento. Poderia ser História, Inglês, Matemática, Economia ou qualquer outra área. Assim eles teriam ferramentas intelectuais para enriquecer o seu processo de formação profissional. Hoje em dia, há muitas pessoas que decidem se tornar professores puramente pela emoção. Elas gostam de crianças: "Ah! Adoro crianças". E eu respondo: "E o que você faz com as crianças quando elas não são tão adoráveis?" (risos). Elas estão aí e nem todas são adoráveis. Mas todos têm direito à educação. Essas pessoas não conseguem ir além dessa visão romântica.

$E$ : - Você poderia nos falar a respeito do programa de formação de professores da Universidade de Wisconsin e dos seus desafios para construir uma formação mais multicultural e anti-racista?

GLB: - A Universidade de Wisconsin assumiu o compromisso, pelo menos conceitualmente, com essa concepção de formação. Se olharmos para quem são os 'arquitetos' do programa de formação docente para o ensino fundamental - Kenneth Zeichner, Michael Apple, Carl Grant, Tom Popkewitz -, essas pessoas lidam diretamente com questões de diversidade cultural, desigualdade social... Entretanto, o sistema de 
premiação da Universidade é organizado de tal modo que os professores universitários se afastam cada vez mais desse programa de formação de professores. Esse é um problema estrutural que estamos enfrentando. $\mathrm{Na}$ verdade, mesmo se todos estivéssemos trabalhando diretamente com os alunos, ainda assim não seríamos suficientes em número para assumir todas as disciplinas do programa. E, mesmo se fôssemos numericamente suficientes, teríamos problemas para manter os alunos de pós-graduação, uma vez que não haveria financiamento para eles. Criamos um sistema que, superficialmente, parece bom, mas que na verdade enfrenta vários problemas. Precisamos constantemente re-assegurar que os alunos de pós-graduação, trabalhando como professores do programa, estejam comprometidos com os princípios que fundamentam a proposta de formação, uma vez que eles têm uma responsabilidade enorme nesse programa. Mesmo que esses alunos de pós-graduação, que atuam como professores, assumam esse compromisso - e eu diria que a maioria dos alunos com quem trabalho assume esse compromisso, pois esse é um dos motivos que os trazem à Universidade de Wisconsin -, eles não possuem o status dos professores titulares. Por uma questão de autoridade, quando eu assumo um curso e me dirijo aos alunos e afirmo: "Este curso é todo ele voltado para a discussão de como fazer com que as crianças se tornem cidadãs num mundo cada mais diverso e multicultural. Não vamos ter apenas uma aula sobre multiculturalismo. O curso inteiro é sobre isso", eles aceitam sem questionar. $\mathrm{O}$ mesmo, quando dito por um aluno da pós-graduação atuando como professor tem um valor bastante diferente. Portanto, essa diferença de status dificulta a implementação dos princípios do programa. Um ponto favorável é que os alunos de pós-graduação são forçados a enfrentar esses conflitos.

$E$ : - Em seus cursos de pós-graduação, você recorre a inúmeras técnicas para que seus alunos se engajem não apenas em discussões teóricas, mas também em uma reflexão sobre identidade. Gostaríamos que você falasse da sua própria experiência docente e do que norteia suas decisões metodológicas e teóricas como educadora.

GLB: - Penso que o que melhor caracteriza minha abordagem de trabalho é a seriedade com que trato o ensino. Não acho que a metodologia seja uma questão secundária. Estou sempre pensando: "Como posso expressar melhor essa idéia, como levar os alunos a uma nova maneira de pensar?" Eu sei que as aulas expositivas não funcionam bem para mim. Há pessoas que são realmente boas nisso. Penso que as pessoas devem envolver-se em seu próprio aprendizado, que elas devem expressar a sua opinião sem sentirem-se reprimidas. E uma das maneiras de conseguir 
isto é dividir as pessoas em grupos. As pessoas falam mais e todos participam. Elas se arriscam mais nesse ambiente. Portanto, eu privilegio grupos de discussão menores. Além disso, preocupo-me em buscar diferentes modos de trabalhar informações e conhecimentos na sala de aula. Algumas vezes uso fitas de vídeo, outras vezes fitas cassete ou ainda literatura popular. Tenho um compromisso com a teoria. Penso que ela é extremamente importante. Entretanto, a fronteira entre teoria e prática não é rígida, é uma 'membrana permeável'. Assim, quando abordo um conceito teórico, estou interessada em mostrar aos alunos como esse se manifesta na prática. Dessa maneira, os estudantes podem mover-se de um modo mais fluido entre teoria e prática.

Estou muito interessada numa teoria de ensino e, mesmo que isso possa soar estranho, creio que um dos motivos pelos quais o ensino é tão ruim é exatamente a falta de uma teorização sobre o ensino. Muitos pensam que ensinar é simplesmente transmitir conhecimento. Profissionais que são referência em sua área muitas vezes não ensinam bem. Os alunos toleram isso porque sabem mover-se bem nesse sistema. É nas escolas de educação infantil que se encontra uma excelente metodologia de ensino. Nessas escolas, os alunos não são facilmente cooptáveis. Eles não permanecem passivos no processo de aprendizagem. Os professores sabem que para ensinar precisam adotar múltiplas metodologias.

$\mathrm{O}$ que estou tentando fazer em minhas aulas é envolver os alunos na avaliação das metodologias que desenvolvo. Quero que eles entendam que não é por acaso que chegamos a um determinado resultado na sala de aula. Esse resultado é fruto de uma concepção metodológica. Resumindo, preocupo-me bastante com a metodologia de ensino. Cheguei na pós-graduação em Currículo pensando que bastava ter o conteúdo 'adequado' para que as coisas funcionassem. Abandonei essa posição ao entender que o conteúdo é apenas um dos componentes e que a metodologia é muito mais importante do que pensava. Ainda mais importante é o que está subjacente à concepção de ensino, ou seja, um conjunto de crenças e o compromisso político das pessoas. Então, mesmo que alguém use um tipo de ensino bastante tradicional, isso pode funcionar porque o que está subjacente na prática dessa pessoa é um pensamento do tipo: "Essas crianças podem aprender e ninguém é capaz de me convencer do contrário". Logo, não se trata apenas de olhar para a relação professoraluno na sala de aula, mas também pensar nas relaçóes sociais mais amplas e na nossa posição em relação ao conhecimento. Se somos críticos a respeito do conhecimento, se entendemos que esse conhecimento está sendo constantemente recriado, reciclado, e que os professores não são 
os detentores de todo o conhecimento, os estudantes são certamente beneficiados. Portanto, eu me 'converti' nos meus últimos anos na Universidade de Stanford. Eu passei a entender que nem tudo dependia do conteúdo. Infelizmente, isso aconteceu quando já havia submetido minha tese que era sobre conteúdo. Eu odiava minha tese, não via a hora de terminá-la, pois o foco estava inteiramente centrado no conteúdo.

$E$ : - Para concluir nossa entrevista, sabemos que você tem contatos com educadores brasileiros como Petronilha Gonçalves e Silva (Professora da Universidade Federal de São Carlos) e outros. Provavelmente pelas suas conversas com eles, você deve ter alguma idéia a respeito de como essas questôes de raça e educação se desenvolvem no Brasil. Você poderia falar a respeito do que conhece da realidade brasileira? Algumas das idéias que você apresentou nesta entrevista podem ser úteis em nossa realidade?

$G L B$ : - Preciso inicialmente apresentar o contexto do meu entendimento sobre o Brasil. Assisti ao filme Orfeu negro quando era muito jovem. Mas, antes de assisti-lo, tinha uma imagem de que o Brasil era o que aparecia nos cartazes das agências de viagem e, até onde saiba, a Garota de Ipanema era branca e loira. Então, algumas coisas aconteceram... Primeiro, assisti a Orfeu negro e isso me deixou boquiaberta. Pensei: "Meu Deus!". E isso fez realmente crescer meu interesse pelo Brasil como um lugar real, diferente daquela representação da indústria do turismo em que as pessoas são brancas ou se são morenas é porque foram à praia e ficaram bronzeadas. Então esse filme fez minha visão do Brasil mudar. Obviamente, conhecer Petronilha foi também muito importante. Além dela, conheci uma outra professora que veio trabalhar com Michael Apple, a Regina Leite Garcia (Professora da Universidade Federal Fluminense). Ela acabava de chegar da Inglaterra. Eu a convenci a participar do encontro da AERA (Associação de Pesquisa Educacional dos Estados Unidos). Então fomos a New Orleans juntas. E quando estou na AERA, pareço uma pessoa diferente porque estou com colegas negros que conheço do país inteiro, e pessoas da Inglaterra e de outros lugares. Então ela encontrou-se com pessoas negras o tempo todo. Então, ela me disse: "Gloria, não há nada parecido com isto no Brasil. Você nunca veria tantos intelectuais negros juntos deste modo". Portanto, eu construí essas duas visões conflituosas sobre o Brasil. De um lado, a que o Orfeu negro havia me oferecido, essa noção de que existe um Brasil negro e de outro, que as desigualdades ainda existem. Outra fonte de informações sobre o Brasil que tenho é por meio do meu irmão que viaja para lá talvez duas vezes por ano. Segundo ele, no Brasil, as pessoas lhe param na rua para dizer: "Você não é daqui". Porque ele anda de terno e 
não é comum que pessoas de cor no Brasil se vistam dessa maneira, entrando e saindo de prédios como aqueles que ele costuma ir. Então, eu tinha essa noção do Brasil como uma 'democracia cultural'. Outra fonte que tinha a respeito do Brasil vem de um homem que teve muita influência sobre minha decisão de fazer a pós-graduação. Ele pertencia à minha igreja e ficamos amigos com o passar do tempo. Ele era um pastor, mas não um pastor convencional, no sentido cristão. $\mathrm{O}$ mínimo que se pode dizer é que ele estava na vanguarda da teologia da libertação. E ele nunca quis ser um pregador. Estava muito mais interessado em saber como conseguir difundir um evangelho de ação social. Ele trabalhava para o Conselho Mundial das Igrejas em Genebra. Seu vizinho era Paulo Freire. Então, havia essa espécie de relação indireta com o Brasil. Quando começamos a trabalhar na Universidade de Santa Clara, Joyce King e eu pensávamos no que poderíamos fazer para 'sacudir' a instituição. Não sabíamos o que fazer. Havia apenas cinco professores negros em todo o campus. Então resolvemos convidar Paulo Freire para vir à Santa Clara. Essa experiência foi muito comovente. Foi fascinante conhecer a respeito do seu trabalho e o quanto era parecido com o que foi realizado nas décadas de 1950 e 1960 no sul dos Estados Unidos. Então, sinto uma espécie de conexão particular com o Brasil. Eu costumava dizer a Petronilha: "O Brasil tem os negros 'ruins', tão 'ruins' que não foram trazidos para os Estados Unidos”. A escravidão promovida pelos europeus na África foi um processo de amansamento e como havia escravos que eles não conseguiam 'domar', eles os deixavam no Caribe ou na América do Sul, senão esses escravos poderiam causar-lhes problemas. Por isto costumo brincar com uma de nossas alunas da Jamaica: "Vocês são os negros 'ruins"” (risos). Então penso no Brasil como um país cheio de negros 'ruins' (risos), o que faz com que meu coração queira sempre estar lá. E também tenho muito interesse pelo movimento de consciência negra no Brasil. Os negros com os quais tenho contato no Brasil finalmente começaram a se livrar dessa mentalidade colonialista, dessa mentalidade de escravo. É preciso entender que existe uma conexão entre os negros da diáspora. Então, este é por assim dizer o pano de fundo sobre o qual penso o Brasil.

A luta que me parece estar acontecendo no Brasil é contra o tipo particular de racismo que existe lá. O Brasil é um país onde é muito difícil para uma pessoa negra avançar. Ao mesmo tempo, há uma combinação de uma dinâmica racial única e de dinâmicas de classe, pois há muitos pobres que não são negros - não quero classificá-los como brancos, pois há uma categoria de 'mestiços', nem branca nem negra, que é profundamente pobre também. Eles descobriram que têm muito a ver 
com os negros. Vemos ocorrer, ainda, uma espécie de sub-educação maciça (os brancos, no entanto, educam seus filhos em escolas particulares). Por outro lado, na minha opinião - eu posso estar sendo muito romântica neste ponto - vocês têm um cidadão muito mais consciente, politicamente. Acho que vocês têm pessoas que entendem que há uma dinâmica bem maior do que simplesmente 'trabalhar duro e chegar lá. As pessoas estão envolvidas em discussões políticas sobre vários ângulos. Um motivo que faz com que eu ache que vocês têm cidadãos mais conscientes politicamente é que as pessoas nas universidades são consideradas 'perigosas'. Nos Estados Unidos, as pessoas nas universidades não são 'perigosas', mesmo que produzam coisas que pareçam 'perigosas', elas são bastante domesticadas pelas armadilhas das relações da classe média e o capitalismo e por toda essas vantagens que elas têm, e, portanto, não se expõem para liderar movimentos sociais ou mesmo participar desses movimentos. No Brasil, vocês têm pessoas nas universidades que querem estar na linha de frente das mudanças sociais. Penso que esse é o lado positivo. Mas a parte pavorosa, com essa incrível globalização, é como conseguir se livrar dessa terrível dívida social? Como tornar a educação de crianças negras e mestiças uma prioridade? Esse me parece ser um enorme desafio, e Petronilha e eu temos falado a respeito das crianças negras e mestiças nas ruas das cidades e da necessidade de que se faça algo por elas. Acho necessário um empreendimento maciço que não pode ocorrer sem a construção de coalizôes. E o Brasil está em uma posição incômoda, porque está cercado por países de língua espanhola que, de algum modo, toleram vocês (risos). Eles deixam vocês serem latinos, mas não querem que vocês realmente sejam latinos. Querem que vocês falem espanhol (risos).

O grande desafio é conectar o Brasil com a diáspora Africana, porque assim se possibilitaria um movimento mais mundial. Um dos motivos pelo qual Petronilha continua trabalhando conosco é porque temos procurado discutir o estado precário da educação dos negros como um fenômeno mundial mais amplo. Não apenas em Chicago ou em Milwaukee, mas também na Inglaterra, África, América do Sul e Caribe, a educação dos negros é terrível. Em qualquer lugar do mundo onde houver negros, a educação deles é muito ruim. E o Brasil há de participar dessa coalizão de pessoas que estão lutando pela educação dos negros, porque, apesar de ser difícil acreditar nisso, estou convencida de que uma melhoria na educação dos negros significa uma melhoria na educação de todos. Não concordo com a idéia de que melhorando a educação dos negros a educação para outras pessoas tornar-se-ia pior. Penso que é uma 
maneira de dizer: "Se estamos mesmo indo em direção à educação para aqueles que estão nas camadas mais baixas, vamos melhorar a educação porque vamos aprender algumas coisas a respeito da maneira como todos podem ser melhor atendidos". Francamente, os brancos não têm uma educação tão boa assim. Na verdade, eles têm muitas outras coisas que os ajudam a ter sucesso.

Recebido em novembro de 2001 e aprovado em maio de 2002.

\section{Nota}

1. Na língua inglesa, a maioria dos substantivos é neutra em relação ao gênero. Sabemos que essa mesma 'neutralidade' não é facilmente traduzida na língua portuguesa. No entanto, a Professora Ladson-Billings é sensível às questões de gênero no conteúdo de sua entrevista. 